\title{
Blogging as Popular History Making, Blogs as Public History: A SINGAPORE CASE STUDY
}

\author{
STEPHANIE HO
}

Public History ReVIew, vol 14, 2007, Pp64-79

\begin{abstract}
$\mathrm{n}$ recent decades there has been growing academic interest about the public's understandings of and attitudes towards the past. Public historians are increasingly aware that to produce meaningful history for the public inherently means having an understanding of popular historical consciousness and memory. This has resulted in a wide range of critical studies on the presentations and popular reception of various media in which the past is related to a public audience. ${ }^{1}$ In the 1990s, American historians Roy Rosenzweig and David Thelen took a more direct approach to the issue and spearheaded a national survey of historical consciousness in North America. ${ }^{2}$ The results of this survey, conducted with 1,500 Americans through telephone interviews, revealed that the past is an integral part of Americans' everyday lives and that they regularly engaged with the past through a range of activities such as attending family reunions, reading books, watching television and visiting museums. Rosenzweig and Thelen described these activities as forms of 'popular historymaking'. ${ }^{3}$ A similar national survey in Australia in the late 1990 s also found Australians actively engaged with the past. The Australian survey further explored the role of places, objects and genealogy in popular history making. ${ }^{4} \mathrm{~A}$ national survey in Canada along similar lines has just commenced.

While the national surveys in North America and Australia demonstrated the universality of popular history making and how the past is intrinsically integral to everyday life, they also revealed that popular history making is generally limited to the intimate and private spheres of family and friends. While national and community histories influence and impact personal histories, there are few opportunities for the common man and woman to participate in the broader sphere of public history. The result is that public history is largely constructed by and reflects the views of state, institutional and academic voices.
\end{abstract}


This situation, however, is changing. In Digital History, David Cohen and Roy Rosenzweig argue that in the past two decades new media and new technologies have challenged historians to rethink the ways that they research, write, present and teach the past. ${ }^{5}$ The World Wide Web, they argue, is not only more open to a global audience of history readers but also to history authors. Given the low barrier to entry, they suggest that that Internet has given 'a much louder and more public voice to amateur historians'.

In this article, I focus on the blog as a dynamic online document that allows ordinary people to simultaneously write private and public history. I argue that blogging is a new form of popular history making that enables ordinary people a greater degree of participation in public history making. Existing on the public domain of the Internet, the blog bypasses traditional forms of mass media such as television, newspaper and book publishing with strong levels of gatekeeping. Among its advantages, blogs allow their authors greater freedom of expression in writing and publishing issues, personal or otherwise, that interests them. Furthermore, the Internet allows bloggers to share their work with a huge international audience. In part because of its potentially wide reach, I contend that blogging is a form of public history as it increases public resources on the past and encourages more democratic history-making processes. This is especially significant in a tightly controlled society such as Singapore where the state dominates almost all aspects of Singapore society and ordinary Singaporeans have few outlets for public debate and expression, as I will discuss later.

This article is organised into four main sections. In the first section I deal with the emergence of the blogging phenomenon and its unique features that encourage a more democratic form of history making. I then explore the Singapore context and discuss two issues: how the state dominates public history and how information technology is a natural resource for Singaporeans to challenge this monopoly. In the third section, I examine two historical blogs in Singapore, analysing how they serve as public resources on history, and encourage greater public engagement and participation in history. At the same time I also investigate specific limitations that restrict the ability of blogs to democratise public history. The article concludes with comments on the impact of blogging on the state of public history in Singapore.

\section{The Blogging Phenomenon}

Blogging is a phenomenon of the twenty-first century. In 1998, there were less than 50 known blogs worldwide. But in October 2006, the Technorati blog search engine was tracking 57.4 million blogs in cyberspace. ${ }^{6}$ Blogging's rate of growth has also reached astounding levels. Technorati estimates that about 75,000 new blogs and 1.2 million posts are made daily and about 50,000 blog updates are made every hour. A Perseus/Websurveyor survey on the state of blogging in August 2005 likened 
the sudden growth of blogging to a geyser: dramatic, unpredictable and trending vertical. $^{7}$

The blog is essentially a type of website where entries are made and displayed in a reverse chronological order such that the most recent entries are displayed first. The blog is also updated frequently. While the definition of the blog continues to evolve, Michael Conniff suggests that most blogs contain the following identifying attributes: ${ }^{8}$

(1) reverse chronological order of entries

(2) unfiltered content

(3) comment functions

(4) hypertext links to other sites

(5) a tendency to excerpt chunks of attributed text from other sources

(6) a 'flip, informal, ironic tone'

Although similar in appearance to personal homepages that have existed since the 1990s, blogs are comparatively easier to set up. In contrast to personal websites whose development were limited to the small number of technically savvy people adept in programming language such as HTML, blogs can be created by almost anyone. Free, online build-your-own-web tools such as Pitas and Blogger, both launched in 1999, provide templates, applications and free server space which automate the technical aspects of blogging thus enabling virtually anyone to easily, quickly and regularly publish their work on the web. ${ }^{9}$

The blog embodies the dual identity of a personal and public medium. Many use it as an online journal, similar to a traditional diary, to record their activities, thoughts and feelings. In this role, the blog's focus is on spontaneous, authentic, personal and subjective content from an individual's perspective. Yet, blogging is also a form of citizen journalism; it acts as a personal soapbox allowing individuals to air their personal views on issues of broader interest. The ability of the blog to transform the nature of public information and thus influence society has generated much enthusiasm. Rebecca Blood, a pioneer in the field, asserts that blogging is causing 'a staggering shift from an age of carefully controlled information provided by sanctioned authorities, to an unprecedented opportunity for individual expression on a worldwide scale. ${ }^{10}$

Dan Burstein and David Kline also argue that blogging has become a key metaphor for interactivity, community building and genuine conversation. ${ }^{11}$ In 2006 , Time magazine named 'you' - the ordinary people who create web-based user content - as their 'person of the year'. The editors argue that it is not longer the elites, states or large corporations who are changing the nature of the information age, and transforming art, politics and commerce. Instead, the accolades go to the ordinary people who create and consume user-generated content such as blogs, 
short videos and podcasts. ${ }^{12}$ It is on such a foundation that this paper explores the potential of blogging in transforming the nature of public history.

\section{SiNGAPORE AS CASE STUDY}

Singapore is a tiny city-state of 697 square $\mathrm{km}$ and a multi-ethnic population of four million people in the heart of Southeast Asia. Regarded as one of the wealthiest, most advanced and cosmopolitan nations in the region, the former British colony has undergone dramatic changes in landscape, economy, standards of living and lifestyle since its independence in 1965. In just two decades since independence, Singapore has transformed from 'third world to first' and from 'mangrove to metropolis'.

However, modern Singapore is somewhat of an oxymoron: it is a modern capitalist state with an open economy, yet it is a nation where the government exercises strong social control over its citizens through its policies, campaigns and imposes severe penalties for disobedience.

Public history is one of the many areas that the state exerts its dominance through its authority over education, heritage institutions and the mainstream media. Schools follow a national curriculum that includes a mandatory component on the history of Singapore taught using the state-produced textbook. Since the late 1990s, the curriculum expanded to include a National Education programme, the main objective of which was to foster in young Singaporeans a sense of identity and pride through knowing the nation's history, 'unique challenges, constraints and vulnerabilities' as well as 'the core values of our way of life'. ${ }^{13}$ Singapore's major museums and heritage institutions are run by the National Heritage Board, a statefunded statutory board. The mainstream media - television stations and press - are indirectly owned by the state and espouse views favourable to the ruling party. The state also has considerable legal powers that enable it to censor or ban public materials which it views to be against public interest. Given this tightly controlled environment, there are few public arenas for ordinary Singaporeans to express their opinions, views and thoughts, especially those that may challenge state narratives. ${ }^{14}$

In the past twenty years, the development of information technology (IT) has been a critical component of Singapore's economic policies. In 1992, the National Computer Board produced a report which outlined the goals and blueprint for information technology development in Singapore:

In our vision, some 15 years from now, Singapore, the Intelligent Island, will be among the first countries in the world with an advanced nation-wide information infrastructure. It will interconnect computers in virtually every home, office, school and factory. ${ }^{15}$

This goal has since been achieved with the development of infrastructure and training. IT has now infiltrated almost all aspects of Singapore life: schools, home, 
work, transport and public service. ${ }^{16}$ A 2005 Infocomm Development Agency of Singapore (IDA) survey revealed that 74 per cent of Singapore households owned a desktop or laptop computer, and 66 per cent of these homes had Internet connectivity. ${ }^{17}$ In its Global Information Technology Report 2003-2004, the World Economic Forum ranked Singapore as one of the most network-ready nations in the world. ${ }^{18}$ Digital technologies look set to become an even more integral part of the Singapore life and economy than they already are. In the latest ten-year master plan for Information Technology development in Singapore, Intelligent Nation 2015 (iN2015), IDA has set the target for Singapore to be world number one in 'harnessing infocomm to add value to the economy and society'. ${ }^{19}$ Some additional targets include ensuring that 90 percent of Singapore homes have broadband access and that 100 percent of homes with school-going children own a computer.

Given the high level of IT development in Singapore, digital technologies and the Internet have become natural and easily accessible resource for information and people-to-people communication. With comparatively lower levels of government control, Internet has become an arena in which alternative discourses emerge ${ }^{20}$ One such example is the Singapore Heritage mailing group which since 2000 has been an influential and active forum for critical discussion on various aspects of Singapore history. ${ }^{21}$ In 2006, the group boasted a membership of 480 from a broad crosssection of Singapore society.

Although initially regarded as a marginal and alternative form of media, the Internet is becoming increasingly mainstream. In addition, blogging, first regarded as a passing fad, has now become ubiquitous part of modern Singapore life. This is especially the case among the young, although not exclusively so. A 2006 survey by the Media Development Authority of Singapore found that 50 per cent of Singapore teens between the ages of fifteen and nineteen have their own blogs. ${ }^{22}$ In addition, the size of the blogging community has grown sufficiently to sustain Tomorrow.sg, an aggregate meta-site dedicated to showcasing Singapore blogs. The community even boasts of a 'blogerati' - a small group of celebrity bloggers such as Mr Brown, Xiaxue and $\mathrm{Mr}$ Miyagi $^{23}$ - who have gained large local following. Although there are laws controlling Internet content, they are mainly aimed at political organizations. ${ }^{24}$ Personal blogs are generally allowed to operate freely, as long as they do not overstep the boundaries such attacking political leaders, making libellous or racial comments. It must be noted that these stringent criterions, however, are not limited to blogs but to any form of public expression in Singapore. Such limitations notwithstanding, blogs offer the opportunity for Singaporeans to participate more actively in the public sphere.

\section{ANALYSIS OF BLOGS}

In recent years, blogs have become a way for Singaporeans to discuss the past. The trend of blogging about past events has been named 'historical blogging'. This 
section uses two case studies of 'historical' blogs to illustrate the unique features of blogs as public history and its limitations for public history making in Singapore. The first case study is Good Morning Yesterday by 53-year-old Lam Chun See, dedicated to his memories of Singapore in the 1960s and 1970s. The second case study looks at Yesterday.sg, an aggregate website initiated by the Museum Roundtable and the National Heritage Board. It hosts blog entries from various individuals around the topic of Singapore memories.

Lam Chun See is possibly Singapore's most well known historical blogger. Lam's blog, Good Morning Yesterday, relates his personal memories of his life in Singapore in the 1960s and 1970s. In his first entry on September 2005, entitled 'Discovering Singapore on Wheels', Lam recounted a cycling trip with his friend in 1969 when the two of them had a 'crazy idea' to cycle around Singapore. In subsequent entries, Lam shared his thoughts and memories about his favourite movies, the primary school he attended, the games he played as a child and the village where he lived. The entries were illustrated with personal photographs and hand drawn maps.

This blog is Lam's personal history. Yet Good Morning Yesterday is more than just an individual's personal history recorded in a personal diary or photo album. It is a public document that adds to the construction of a public history of Singapore. Lam's blog can be regarded as public history for several reasons. Firstly, the blog is written largely for the benefit of the public, not just his family and friends. In his profile, Lam writes that the blog is meant for 'Singaporeans and friends of Singapore' with the purposes of allowing people of his generation to 'share stories of Singapore back in the kampong days when we were kids' and for 'our kids' to 'visit this site and learn a bit about our past'. Related to this, the blog is easily accessible by the public. Anyone can access Lam's blog if they are connected to the Internet. Lam does not restrict the blog to selected readers by protecting it with a password.

Secondly, Lam's blog is public history due to the content of his blog. Although Lam writes of his private memories, these memories of places, events and activities are not exclusive to Lam's experience but common to many others of his generation. For example, he writes about popular public places such as Beauty World, a popular shopping area, and the experiences of eating a popular local dessert - an ice ball. These places and experiences, which have now disappeared, were shared by many Singaporeans of his generation. Older readers are encouraged to share their own memories of those times through comments and posts. In this manner, Good Morning Yesterday is more than just a site for personal recollection; it functions as a place for discussion and joint reminiscing of a common past.

For younger audiences, these stories of the past in photographs and text, legitimated and enhanced stories of they past they heard from their own family members. One reader, Lina, wrote that the blog allowed her to finally 'put a picture to 


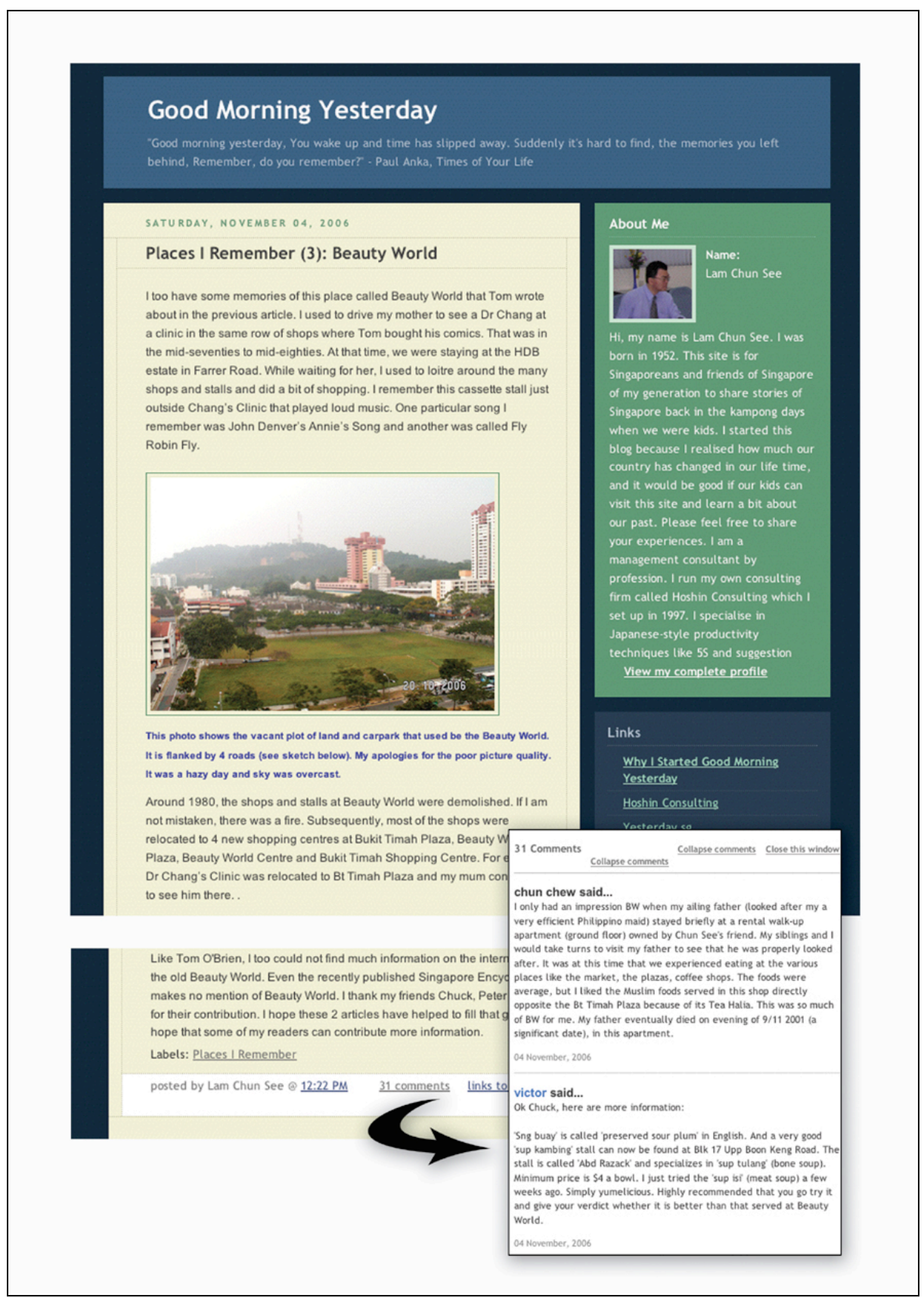

Figure 1: Composite of screenshots from Good Morning Yesterday. Available at http://wwwgoodmorningyesterday.blogspot.com, accessed 23 November 2006 
the old memories' she heard from her grandmother. ${ }^{25}$ Terminalcase42 wrote that the blog 'reminded me of just how different Singapore and Singaporeans were just a few decades ago'. Another, Etel, wrote: I 'really, really love your blog because it made me understand so much more about olden Singapore'. Lam's blog has gained a following among the younger audience. On 29 November 2005, Lam wrote:

Ever since Ivan Chew submitted this blog to Tomorrow.sg I have received many visits from young Singaporeans. I am truly heartened and encouraged by their kind remarks. I particularly love this one by yl: "wahhhhhh!!!!!!Uncle!!YOU ROCK!!!!"

YOU ROCK! seemed to sum up the general sentiment about Lam's blog from the young Singaporeans. One possible reason why Lam's blog 'rocks' is that it offers a different perspective to Singapore's past to that presented in the school history textbook. Singapore history is taught as a compulsory subject in the secondary school curriculum and concentrates on political developments. The 1960s in Singapore is portrayed as a time of upheavals and civil disorder where strikes, riots and curfews were the order of the day. Lam, on the other hand, avoids politics and writes about the activity of day-to-day living in the 1960s. He writes about places such as the kampong or local village he grew up in, objects such as the toys he made and the cameras he used and activities such as cycling, fishing and climbing trees. Thus, Good Morning Yesterday offers a different and possibly more immediately relevant perspective of Singapore's past. His blog increases the public resources of Singapore's social history, especially on the everyday aspects on Singapore's past.

The third reason for regarding Good Morning Yesterday as public history is its capacity to serve as a starting point for a public and collective construction of history. With each new entry Lam initiates a conversation on a topic with readers. The latter engage with Lam and one another by adding their comments which are posted on Lam's blog. In this way, conversations around the topic emerge and together, they dynamically describe and re-describe, construct and re-construct particular aspects of Singapore's history. To illustrate this point, I refer to two entries in Good Morning Yesterday related to Beauty World, a popular shopping area. On 1 November 2006, Lam posted the article 'Tom O'Brien remembers Beauty World' where Tom, a British citizen who lived in Singapore as a child, described his activities in the Beauty World of the 1960s. Three days later, Lam posted a second entry of his own memories of Beauty World with photographs. In his entry, Lam also included two short pieces by his friends, Chuck and Peter, who once lived around that area. In response to these articles, readers made additional points in the comment forum. These included comments from Lam's brother, Chun Chew, who shared his own memory of the area. Regular readers, Victor and Peter, separately pointed out errors in the Beauty World 
map that was posted by O'Brien. These errors were subsequently corrected. In this way, the history of Beauty World is constructed by the initial entries and the exchanges that emerged. This conversation about Beauty World and the writing of its history is on going; it will remain open for as long as the blog is on the Internet and as new readers discover it and contribute to this conversation.

However, as part of public discourse Good Morning Yesterday is subject to restrictions placed on public expression in Singapore as mentioned earlier. Since the growth of the Internet, the state has set in place a body of legal restrictions to monitor Internet content. While actual legal action against individuals is rare, there have been several instances where the government has used or threatened to use its legal powers. This is sufficient to cultivate an environment where groups and individuals are very careful with what they write online, to the point of self-censorship. As popular Singapore blogger, Mr Brown, wrote: 'Singapore has four climates. Climate of hot. Climate of hotter. Climate of hottest. And Climate of fear'. ${ }^{26}$ In the instance of Good Morning Yesterday, Lam has chosen to create a site that aligns itself with the national agenda and avoids controversial or political topics. For example, in the sidebar of his blog, Lam even includes a quote from the Prime Minister that reads:

We have to tell the Singapore story... Parents and grandparents have a role to play. You have to tell the stories to your children, to your grandchildren to know not only what happened but how you feel about it.

As such, Lam's stories become part of the national narrative, the 'Singapore Story', and this blog a means by which Lam fulfils what he regards as his duty of passing on stories of the past to the younger generation.

Avoiding political topics, none of Lam's entries discuss his memories of important political developments that occurred in the 1960s such as Singapore's independence or race riots. The reasons for the silence on these events can be deduced by his reply to a suggestion from a young reader. This reader suggested that Lam incorporate entries on moral and social issues such as premarital sex, drinking and filial piety in his blog. Lam replied that it was 'inadvisable to go into those areas'. For Lam, blogging on such issues was 'too much work' as these were 'serious issues' that required 'careful thinking'. He also said that as these were 'rather sensitive topics' and he would probably not use his real name if he were to blog about them. ${ }^{27}$ This last point regarding anonymity on the Internet attests to the population's strong awareness of the state concerns over public expressions of 'sensitive issues'. This, however, has not stopped Singaporeans from creating websites, usually hosted on a foreign server, that are more critical and challenging of government policies and narratives. This will be further discussed below.

Riding on the popularity of 'historical blogging', the National Heritage Board (NHB) together with the Museum Roundtable Committee sponsored and launched a 
heritage blog in $2006 .{ }^{28}$ According to NHB's Corporate Communications Director, Walter Lim, the aim of the blog is to serve as a platform to share heritage-related content and become a 'rallying point to bring people together to discuss our heritage'. ${ }^{29}$ The blog, named Yesterday.sg, was launched in February 2006 and modelled after Singapore meta-site, Tomorrow.sg. As a meta-site, Yesterday.sg hosts entries from various contributors which are reviewed by a team of editors. With the help of promotions such as a weekly heritage quiz, a 'refer a friend' campaign and a 'vote for your favourite blog post' competition, yesterday.sg received more than 30,000 hits in its first month. ${ }^{30}$ The setting up of this blog is significant in that it recognises that Singapore's national history is not just the story of the state but also one 'made up of individual recollections'. ${ }^{31}$ This seemingly signals a new direction in public history which the state had previously monopolised with its tight control over the school history curriculum, national exhibitions and other writings of Singapore history in the mass media. In a sense, Yesterday.sg can be seen as a democratisation of history making in Singapore as it encourages ordinary people to participate in writing history through sharing personal stories on the blog.

While Yesterday.sg is theoretically a resource for public history making, in practice it has yet to achieve this aim. The initial flush of readership and public contributions was not sustained. An examination of entries made in December 2006 shows that the majority of the entries (22 out of 34) were written by editors of the blog or posted by 'friends' of Yesterday.sg. 'Friends', described as 'founding members' of Yesterday.sg who are committed to writing articles for it, contribute articles similar to Lam's recollections in Good Morning Yesterday. ${ }^{32}$ For example, 'friend' Victor posted his recollection of taxis in the past in an entry entitled 'Days of Pa-Ong-Chia and Shared Taxis' (posted 16 December 2006). The co-option of existing popular 'heritage' bloggers such as Koo and Lam as 'friends' has ensured a steady stream of personal contributions to the blog. Thus Yesterday.sg has become a showcase of existing voices online but has yet to encourage new voices to emerge. Editors are responsible for the majority of the posts which serve as subtle and not-so-subtle advertising for NHB exhibitions and activities such as glowing exhibition reviews (for example, My NUS Jaunt Part 1 and II, posted 7 and 8 Deceember 2006 by Angela) and publicity materials for NHB activities (for example the Countdown party at the National Museum, posted on 30 December 2006). However, with the exception of entries related to competitions, Yesterday.sg entries attract few readers and even fewer comments. For the month of December 2006 there were only eight comments made on Yesterday.sg. Generally, there are very few comments for most entries on Yesterday.sg. In contrast to Lam's Good Morning Yesterday blog, the six entries he posted during the same period of time received 64 comments. In a medium where 'traffic is currency,33 and content is regarded as 'just a medium for interaction between people', ${ }^{34}$ Yesterday.sg has failed in its aim to engage the public. 


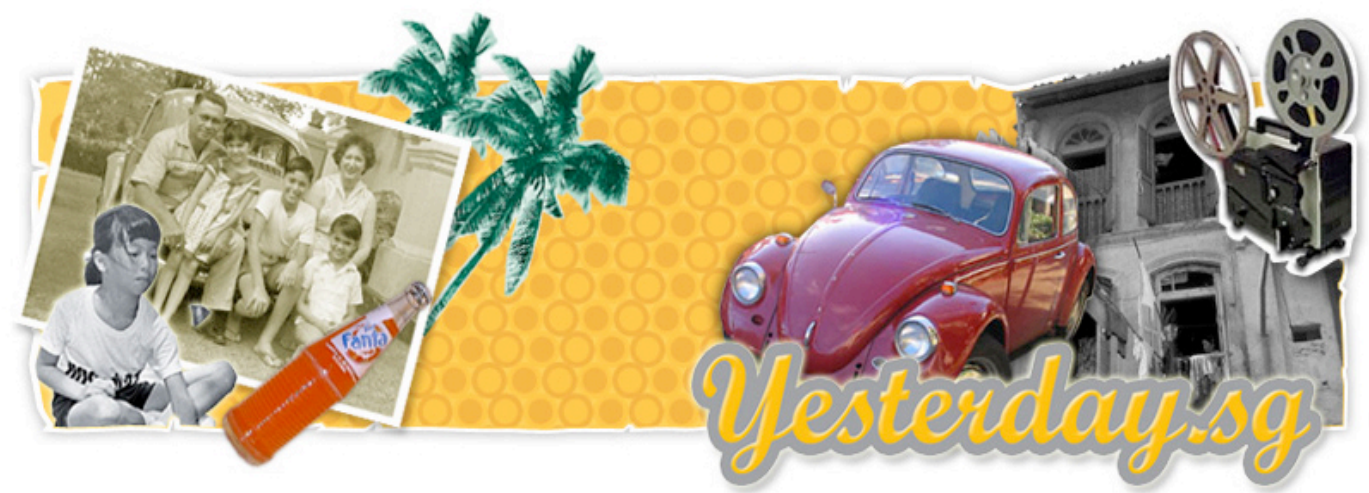

Check this out!
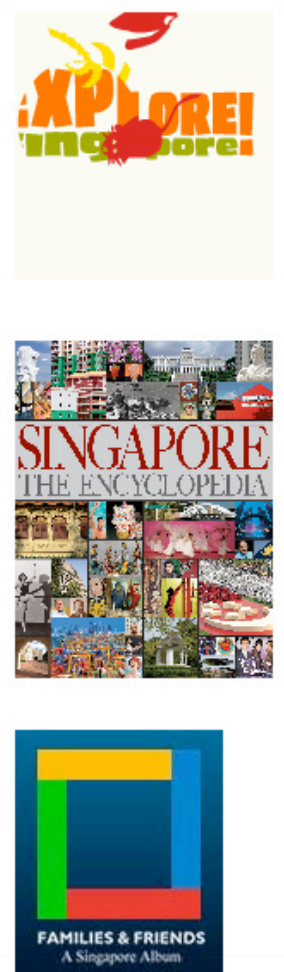

Oh my darling Clementi!

November 09, 2006

Changes in Clementi Town Centre, for better or worse.

The rambling leaf writes in her blog on the impending transformation of

an established town centre and how the changes will wipe out more than just trees and tarmac...

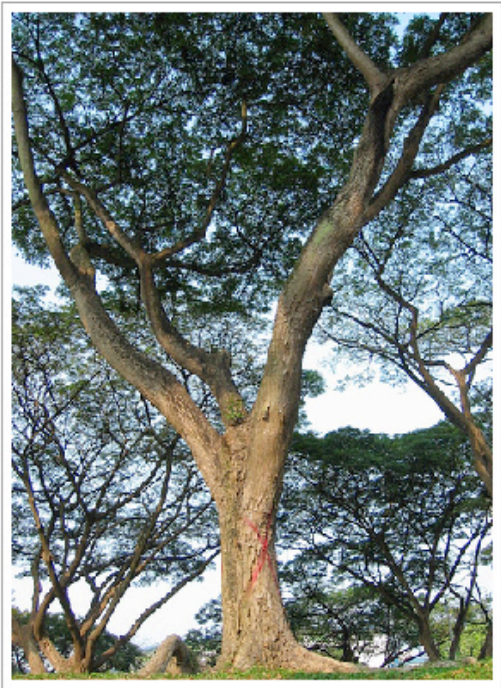

Read on

Posted by budak on November 09, 2006 at 07: 13 AM

Termalink
Sign up as a member and share your stories with us!

$\longleftarrow$ Sign me up now

$\checkmark$ Help me! I'm facing problems signing up

$\checkmark$ Why should I join as a member?

Member login

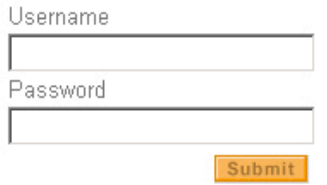

× Forgot your password?

Subscribe to us!

By Feeds

RSS 2.0

$\triangle$ Atom

Or news aggregators

\begin{tabular}{|l|l|}
\hline U & FEEDEURNER \\
\hline
\end{tabular}

\begin{tabular}{|l|l|}
\hline SUB & BLOCLINES \\
\hline
\end{tabular}

+ MY YAHOO!.

$\Phi$ Add to Google

Mailing List

Figure 2: Screenshot of Yesterday.sg homepage. Available at http://www. Yesterday.sg, accessed 9 November 2006 
There are several possible reasons for readers' apathy regarding reading and participating in Yesterday.sg. Firstly, Yesterday.sg lacks many of the features that make blogs popular. These include timely information that is largely unmediated by institutions and commercial demands. While Yesterday.sg is updated frequently with the latest news and activities of its institutional sponsors, the blog has a strong corporate tone. This is manifested in the large number of posts by NHB-affiliated editors and the heavy promotion of NHB sponsored activities and products through the entries as well as advertisements on the side bar. In addition, NHB acts as gatekeeper to the site. To contribute an entry, one would have to first register as a member and agree to its conditions such as refraining from posting messages that are 'obscene, vulgar, slanderous, hateful, threatening, or that violate any laws' ${ }^{35}$ Editors are given the right 'to edit, or move any messages for any reason'. Although these are common terms and conditions for contributing to a public site, they have however, detracted from the purpose of the blog - freedom of personal expression and editorial control over their entries.

The lack of an option for anonymity on the website is another possible reason for the unpopularity of Yesterday.sg. The unavailability of anonymity means restriction and self-censorship when contributing entries to the blog site. Some of the most challenging websites are anonymous and hosted on foreign servers placing them out of the range of local authorities. One such example is New Sintercom, a website dedicated to free speech on Singapore society. In an email interview with local daily The Straits Times, the editor of the website defended his anonymity. He wrote:

I feel we represent a cross-section of Singaporeans who want to be active citizens but who feel (shall we say) discouraged by the government record of curbing free speech. The good thing about the Internet is that we can speak freely, albeit anonymously. ${ }^{36}$

The third reason for Yesterday.sg's unpopularity is the public's cautious attitude of engaging in the public sphere, especially on a state-sponsored site. As mentioned earlier, such caution is a result of a particular Singaporean understanding of the idea of freedom of speech in Singapore. This attitude has developed in a context where legal and police action has been threatened and used against bloggers and where there is ambiguity over permissible online content. Various cases in 2005 seem to justify the blogging community's exercise of care when writing online. In September, two bloggers were arrested and sentenced under the Sedition Act for posting extreme racist remarks offensive to the minority Muslim-Malay community in their blogs. One of the bloggers was jailed for a month while the other was imprisoned for a day and fined the maximum penalty of about US $\$ 2,960 .{ }^{37}$ While these two instances were straightforward violations where the offenders would have faced 
similar repercussions action in many other countries, it nevertheless reinforced the perception of a climate of fear where public expression is concerned.

Two other cases were less cut and dried. In May 2005, two Singapore students, former scholar Chen Jiahao and engineering student Jeremy Chen were taken to task by the Agency for Science, Technology and Research ( $\left.A^{*} S t a r\right)$ for allegedly making defamatory remarks about the agency in their blogs. ${ }^{38}$ While Jeremy Chen's case was amicably settled, Chen Jiahao was threatened with a libel suit for criticizing the agency's scholarship policies and its chairman Philip Yeo. The suit was eventually retracted when Chen Jiahao apologised 'unreservedly' and shut down his blog. But Chen remained critical of the agency's actions. He told Dow Jones International News:

I am disappointed and discouraged that $\mathrm{Mr}$ Yeo had not attempted to correct any possible misconceptions that I have had over the interpretation of publicly available information, deciding instead to threaten me with defamation... I cannot say that such actions have promoted the cause of getting younger Singaporeans to speak out.

In the international press, Paris-based Reporters Without Borders said that Chen's remarks were critical but not defamatory. It felt that the case highlighted the lack of free expression in Singapore which is among the twenty lowest-scoring countries in the organisation's worldwide press freedom index. The Committee to Protect Journalists (CPJ) also voiced their concern that the Singapore government has 'raised the spectre of costly legal action to chill commentary on the Internet'.

State monitoring of online content in Singapore goes beyond libel and defamation cases with the government being especially sensitive to online content that venture into politics. During the 2006 national elections, podcasts and videocasts (or vodcasts) related to the elections were explicitly disallowed. ${ }^{40}$ Penalties for breaching these regulations are a fine of up to US\$1,000 or a maximum twelve-month jail term or both. Beyond the election period, the Media Development Authority (MDA) Internet Code of Practice prohibits online content that goes against 'public interest, public morality, public security' and 'national harmony'. Given the broad scope of these prohibitions, political watchers and civil society advocates have time and again called for the government to 'spell out what's acceptable comment in cyberspace, when and how it will act, and not use a "sledgehammer" to kill a fly'. ${ }^{41}$ The state has not responded to these calls, instead leaving Singaporeans to second guess what is and is not permitted in cyberspace. This uncertainty has led Singaporeans to generally keep to a safe route and avoid discussing politics or even political history in the public sphere. ${ }^{42}$

Despite the cases mentioned earlier and the environment of fear discussed, at present the state exercises a comparatively lighter hand on blogs and online content 
than on the mainstream media. In a television interview in 2006, Minister for Information, Communications and the Arts, Dr Lee Boon Yang, described blogs as 'internet chatter' which could largely be left alone. He added that the government asserts more control over traditional media because its feels that mainstream newspapers 'must report accurately, objectively and responsibly' and adopt the model that they are part of the state's nation-building effort. ${ }^{43}$ Thus, blogging still emerges as a viable medium for Singaporeans to engage in the public sphere, albeit with a certain level of restraint and caution.

\section{CONCLUSION}

The analysis of the two case studies in this article demonstrates that blogs can be a vehicle for ordinary Singaporeans to write, discuss and engage with public history in the twenty-first century. The case of Good Morning Yesterday indicates that the blog is most successful as public history and encouraging democratic history-making practices when it emphasises the person-to-person connection that embodies the original ethos of the blog. Blogs such as Good Morning Yesterday increase public resources and promote more active engagement with the past. While Yesterday.sg also seeks to encourage more personal stories of the past into the public sphere, Singaporeans are cautious in engaging with history on this site. Institutional blogs such as Yesterday.sg are less successful because of its higher level of gatekeeping, its corporate personality and the fear factor associated with public participation on a state-sponsored site. The case of Yesterday.sg demonstrates that the form of the blog alone is insufficient to encourage public engagement in the past. It draws attention to the reality that whilst their blogs exist on the Internet, bloggers reside within specific national boundaries and their blogs are thus affected by the specific limitations of their environment.

The particularities of the Singapore context have enabled blogs as personal history to operate generally unrestricted, but blogs which engage in public form of history making to operate with caution. Given this situation, blogs at present act as additional rather than alternative sources to the mainstream. In Good Morning Yesterday, Lam's personal stories deal with social history in Singapore in the 1950s and 1960s but they do not contradict or challenge official political narratives of that period. Hardly any of the entries on Yesterday.sg deal with political events in the past. Currently, bloggers have not yet used the blog to construct public histories that have challenged state narratives, allowing the state to maintain its monopoly over the construction of Singapore's political past.

The potential for the blogosphere to become an exciting and more democratic arena for ordinary people to participate in history making is heightened by the increasing digitisation and connectedness of not only Singapore but the world. Through blogging, ordinary citizens are able to present their stories and jointly construct public histories more reflective of their lived experiences. The challenge in 
the Singapore context will come when bloggers venture beyond the safe arena of memory and nostalgia and create histories that are incompatible with state narratives. It remains to be seen whether the state will treat it as 'internet chatter' or bring in the long arm of the law.

\section{ENDNOTES}

1 See, for example, George Lipsitz, Time passages: collective memory and American popular culture, Minneapolis, University of Minnesota Press, 1990 and Raphael Samuel, Theatres of Memory, London, Verso, 1996.

2 See Roy Rosenzweig and David Thelen, The Presence of the Past: Popular uses of history in American Life, Columbia University Press, 1998.

3 ibid, p18.

${ }^{4}$ See Paula Hamilton and Paul Ashton (eds), Australians and the Past, special issue of Australian Cultural History, vol 22, 2003.

${ }^{5}$ Daniel J. Cohen and Roy Rosenzweig, Digital history: a guide to gathering, preserving, and presenting the past on the Web, University of Pennsylvania Press, Philadelphia, 2005.

${ }^{6}$ Figures as given on 23 October 2006 at http://www.technorati.com/about.

7 See Perseus/Websurveyor (2005) The Blogging Geyser, [online] available at http://www.perseus.com/blogsurvey/geyser.html, accessed 11 October 2006.

8 Michael Conniff, Just what is a blog, anyway? (posted 29 Sept 2005), USC Annenberg, Online Journalism Review, available at http://www.ojr.org, accessed 22 Sept 2006.

9 For an overview on the development of blogging, see Rebecca Blood, 'Weblogs: A History and Perspective', Rebecca's Pocket, online available at http://www.rebeccablood.net/essays/weblog_history.html, accessed 11 October 2006.

${ }^{10}$ ibid.

${ }^{11}$ Dan Bustein, 'Introduction', Blog! How the newest media revolution is changing politics, business and culture, New York, CDS books, 2005, pxxi.

${ }^{12}$ Richard Stengel, Now It's Your Turn, Time, New York, 25 December 25 2006/ 1 January 2007, vol 168, iss 26, p8.

${ }^{13}$ Hsien Loong Lee, 'The Rationale for National Education', Speech at the launch of National Education, 17 May 1997.

${ }^{14}$ See Ooi Giok-Ling, 'Civil society, democracy and the role of the media in Singapore', MediaAsia, vol 27, no 4 2000, pp 200-4 and David Birch and Marianne Phillips, 'Civic of civil contingencies: Regulating television and society in Singapore', in Philip Kitley (ed), Television, regulation and civil society in Asia, Routledge Curzon, London, 2003.

${ }^{15}$ National Computer Board, A Vision of An Intelligent Island: IT 2000 Report, Singapore, National Computer Board, 1992.

${ }^{16}$ M. Arun and M. T. Yap, 'Singapore: The Development of an Intelligent Island and Social Dividends of Information Technology', Urban Studies, vol 27, no 10, 2000.

${ }^{17}$ See Infocomm Development Authority of Singapore, 'Annual Survey on infocomm usage in households and by individuals for 2005', [online] available at http://www.ida.gov.sg, accessed 22 September 2006.

${ }^{18}$ Infocomm Development Authority of Singapore, 'At a glance: Infocomm usage in Singapore', 2004 [online] available at http://www.ida.gov.sg, accessed 14 September 2006.

${ }^{19}$ Infocomm Development Authority, Innovation, 'Integration. Internationalisation. Report by the iN2015 Steering Committee', Singapore, Infocomm Development Authority, 2005, p15.

${ }^{20}$ See George Cherian, 'Singapore: Media at the mainstream and the margins', in Russell Heng (ed), Media Fortunes, Changing Times, ISEAS, 2002 and K.C. Ho, Zaheer Baber and Habibul Khondker, 'Sites of resistance: alternative websites and state-society relations', British Journal of Sociology, vol 53, no 1, March 2002.

${ }^{21}$ The group's public website is online at http://groups.yahoo.com/group/singaporeheritage but membership is required to read posts made to the group.

${ }^{22}$ H. H. Chua, Singapore's blog happy teenager, Straits Times, 10 November 2006.

${ }^{23}$ To read their blogs see http://www.mrbrown.com, http://www.xiaxue.blogspot.com and http://www.migayi.sg.

${ }^{24}$ See Garry Rodan, 'Embracing electronic media but suppressing civil society: authoritarian consolidation in Singapore', The Pacific Review, vol 16, no 4, 2003.

${ }^{25}$ Comments made to Lam's entry 'About my photos' 29 November 2005, [online] available at http://www.goodmorningyesterday.blogspot.com, accessed 22 September 2006. 
${ }^{26}$ Quoted in S. J. Chan, 'Singapore: Freedom of blog speech depends on who they insult', Inter Press Service, 18 November 2005.

${ }^{27}$ Comment by Lam Chun See to 'About your photos', posted 30 November 2005. Available at http://www.goodmorningyesterday.blogspot.com, accessed 22 September 2006.

${ }_{28}$ The Museum Roundtable is a committee of 43 museums in Singapore. Established in 1996 and chaired by the National Heritage Board, the Museum Roundtable seeks to develop a stronger museum-going culture in Singapore and position museums as unique and fascinating cultural destinations. See http://www.museums.com.sg/aboutus.asp.

${ }^{29}$ Radio interview with Walter Lim on The Breakfast Club, Singapore News Radio 93.8FM, 6 March 2006, 7:09am.

30 J. J. Rasuljulianar, 'It's yesterday once more', TODAY, 23 March 2006.

${ }^{31}$ Conscious effort to ensure human-speak, Straits Times, 25 August 2006.

${ }^{32}$ Victor Koo, 'Speak No Evil, Only Heritage and Nostalgia', Taking up the Challenge, [online] available at http://victorkoo.blogspot.com/2006/03/speak-no-evil-only-heritage-and.html, accessed 1 December 2006.

${ }^{33}$ R. Blood, 'Introduction', We've got blog, Perseus Publishing, 2002.

${ }^{34} \mathrm{D}$. Rushkoff, 'The internet is not killing off conversation but actively encouraging it', Blood, We've got blog.

${ }^{35}$ See http://Yesterday.sg/member/register, accessed 15 January 2007.

${ }^{36}$ Interview with New Sintercom Editor, Straits Times, 27 April 2002, [online] available at http://www.newsintercom.org, accessed 25 August 2006.

37 S. J. Chan, 'Singapore: Freedom of blog speech depends on who they insult', Inter Press Service, 18 November 2005.

${ }^{38}$ M. Y. Ng, 'Blog no evil', Straits Times, 15 May 2005.

${ }^{39}$ G. DeClercq, 'Singaporean shuts blog, apologises after libel threat', Reuters News, 9 May 2005.

${ }^{40}$ C. Chang, 'Will blogs on politics be shut down?' The New Paper, 16 September 2005.

${ }^{41}$ S. J. Chan, 'Singapore: Freedom of blog speech depends on who they insult', Inter Press Service, 18 November 2005.

${ }^{42}$ See James Gomez, 'Internet politics: surveillance and intimidation in Singapore', Singapore-Bangkok, Think Centre, 2002, p20.

${ }^{43}$ Channel News Asia, 'Unjustified comments on government politics will undermine confidence in Government: Minister', Channel News Asia, 12 July 2006. 